\section{SPEED SENSORLESS CONTROL FOR PMSM DRIVES USING EXTENDED KALMAN FILTER}

Mohamad Ikhwan Nordin, Jurifa Mat Lazi*, Md Hairul Nizam Talib, Zulkifilie Ibrahim

Faculty of Electrical Engineering, Universiti Teknikal Malaysia Melaka, Hang Tuah Jaya, 75450 Ayer Keroh, Melaka, Malaysia
Article history

Received

1 July 2021

Received in revised form

27 September 2021

Accepted

7 October 2021

Published Online

20 December 2021

*Corresponding author jurifa@utem.edu.my

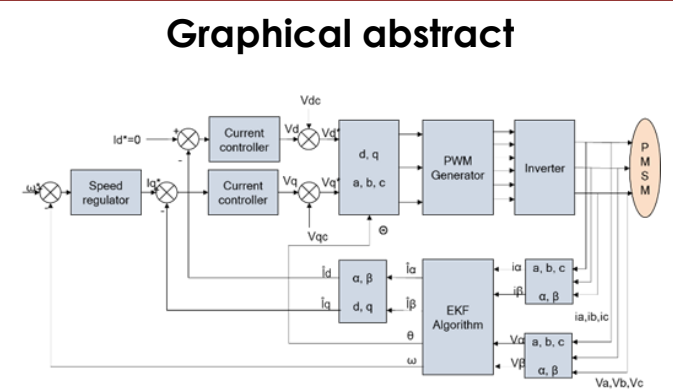

SENSORLESS PMSM DRIVE USING EKF

\begin{abstract}
In this paper, Sensorless Permanent Magnet Synchronous Motor (PMSM) using Extended Kalman Filter (EKF) is presented. The previous PMSM drive uses a sensor to measure the motor's speed. Then the idea is to replace the sensor by using sensorless drives based on the observer. For the conventional observer, it's only good for low current and low-speed applications. Moreover, it is hard to detect the phase voltage due to the non-existence of neutral wire. Therefore, this project proposes sensorless control using an EKF. This method provides an optional estimation algorithm for the non-linear system that can produce a fast and accurate estimation of state variables. The accurate estimation will reduce the noise and ripple of the system. Additionally, the EKF do not require the information of mechanical parameters and the initial position of the rotor, making the construction is easy and simple. In this paper, the fundamental of the EKF algorithm is explained and the simulation results for different speeds and loads are presented. The noise reduction test is also conducted to measure the flux current with and without the filter. The simulation study is achieved using MATLAB/Simulink to verify the effectiveness of the proposed method. The results of the simulation show that the sensorless PMSM drives using EKF have lower overshoot and faster rise time during start-up conditions and have lower undershoot during the loaded condition. It also can be concluded that the proposed sensorless PMSM drive using EKF has good speed control accuracy and can reduce the current noise.
\end{abstract}

Keywords: Permanent Magnet Synchronous Motor (PMSM), Extended Kalman Filter (EKF), Sensorless Drive, Noise reduction

\begin{abstract}
Abstrak
Dalam kertas kerja ini, Motor Segerak Magnet Kekal (PMSM) Tanpa Sensor menggunakan "Extended Kalman Filter" (EKF) adalah dibentangkan. Pemacu PMSM sebelumnya menggunakan sensor untuk mengukur kelajuan motor. Kemudian ideanya adalah untuk menggantikan sensor dengan menggunakan pemacu tanpa sensor menggunakkan "observer". Bagi "observer" konvensional, ia hanya baik untuk aplikasi arus rendah dan kelajuan rendah. Selain itu, sukar untuk mengesan voltan-fasa kerana ketiadaan wayar neutral. Oleh itu, projek ini mencadangkan kawalan tanpa sensor menggunakan EKF. Kaedah ini menyediakan algoritma anggaran untuk sistem bukan linear yang boleh menghasilkan anggaran pembolehubah keadaan yang cepat dan tepat. Anggaran yang tepat akan mengurangkan bunyi dan riak sistem. Selain itu, EKF tidak memerlukan maklumat parameter mekanikal dan kedudukan awal rotor, menjadikan pembinaannya mudah dan ringkas. Dalam kertas ini, asas algoritma EKF diterangkan dan keputusan simulasi untuk kelajuan dan beban yang berbeza dibentangkan. Ujian
\end{abstract}


pengurangan hingar juga dijalankan untuk mengukur arus fluks dengan dan tanpa penapis. Kajian simulasi dicapai menggunakan MATLAB/Simulink untuk mengesahkan keberkesanan kaedah yang dicadangkan. Keputusan simulasi menunjukkan bahawa pemacu PMSM tanpa sensor menggunakan EKF mempunyai overshoot yang lebih rendah dan masa naik yang lebih cepat semasa keadaan permulaan dan mempunyai undershoot yang lebih rendah semasa keadaan dimuatkan. la juga boleh disimpulkan bahawa pemacu PMSM tanpa sensor yang dicadangkan menggunakan EKF mempunyai ketepatan kawalan kelajuan yang baik dan boleh mengurangkan hingar semasa.

Kata kunci: Permanent Magnet Synchronous Motor (PMSM), Extended Kalman Filter (EKF), Pemacu Tanpa Sensor, pengurangan bising

(C) 2022 Penerbit UTM Press. All rights reserved

\subsection{INTRODUCTION}

Among the AC motor drives, PMSM drive systems have a famous demand in many industrial applications. PMSM is used in low to medium power applications. The features of the motor are simple structure, reliable operation, better energy efficiency and high power density [1-5]. In our market, PMSM drive systems come with a shaft sensor such as an optical encoder, hall effect sensor or resolver to measure the speed of the rotor, torque current and flux current. The total number of the sensor will cause the complexity of the model and weight of the system. Besides that, it will increase the cost of the model and effected the reliability of the drive system. In some applications, it is impractical to link the actual sensed speed or current signal from the load to the controller because of the heavy or harsh environment and excessive wire length. Speed and current or other parameters for sensorless control of motor drive remarkably reduce the system complexity, narrow the cost, minimize the weight and improves the overall system reliability and dynamic performance. From this remarkably benefits have prompted the research and technology development of sensorless control. Many algorithms control methods have been studied and report for the speed, torque and any other parameters control of the PMSM drives [6-9]. Basically, few estimation methods for the speed and position estimation block have been reported. The first method is by using Model Reference Adaptive System (MRAS) [10-11]. Secondly is by using Luenberger Observer [12-13]. Then, the other method is using Reduce Order Observer [14-16]. Other than that, the estimation also can be done by using Sliding Mode Observer [17-19]. Lastly, the Extended Kalman Filter (EKF), is also one of the methods that researchers used in estimation for speed drives [21-23]. This current project chooses the estimation method using EKF as it is perfectly suited to solve the noise reduction, robustness and linear problem as these problems usually appeared in conventional estimators for sensorless PMSM drives.

\subsection{MODELLING SENSORLESS PMSM DRIVE}

A. Mathematical Model of PMSM Drive

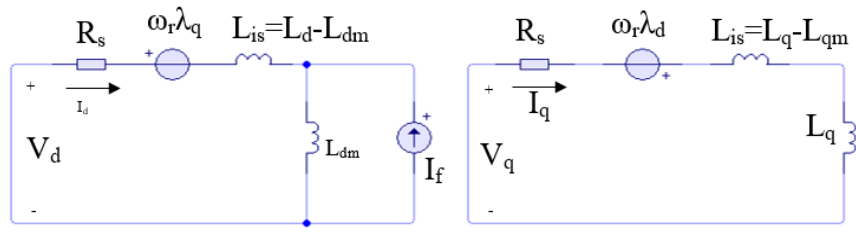

Figure 1 Equivalent circuit of PMSM drive without damper windings

Figure 1 presents the equivalent of PMSM drive without damper windings and the voltage equations with respect to rotor axis are given by;

$V_{q}=R_{s} i_{q}+\omega_{r} \lambda_{d}+\rho \lambda_{q}$

$V_{d}=R_{s} i_{d}-\omega r \lambda_{d}+\rho \lambda_{d}$

Flux linkages are given by:

$\lambda_{q}=L_{q}+i_{q}$

$\lambda_{d}=L_{d} i_{d}+\lambda_{f}$

Substituting Equations (3) and (4) into (1) and (2):

$V_{q}=R_{s} i_{q}+\omega_{r}\left(L_{d} i_{d}+\lambda_{f}\right)+\rho L_{q} i_{q}$

$V_{d}=R_{s} i_{d}-\omega_{r} L_{q} i_{q}+\rho L_{d} i_{d}+\lambda_{f}$

Arranging Equations (5) and (6) in matrix form:

$\left[\begin{array}{l}V_{q} \\ V_{d}\end{array}\right]=\left[\begin{array}{cc}R_{s}+\rho L_{q} & \omega_{r} L_{d} \\ -\omega_{r} L_{q} & R_{s}+\rho L_{d}\end{array}\right]$

The developed motor torque is being given by: 
$T e=\frac{3}{2}\left(\frac{p}{2}\right)\left(\lambda_{d} i_{q}-\lambda_{q} i_{d}\right)$

The mechanical Torque equation is:

$T_{e}=T_{l}+B \omega_{m}+J \frac{d \omega_{m}}{d t}$

Solving for the rotor mechanical speed form Equation (9):

$$
\begin{aligned}
& \omega_{m}=\int\left(\frac{T_{e}-T_{l}-B \omega}{J}\right) d t \\
& \omega_{m}=\omega_{r}\left(\frac{2}{P}\right)
\end{aligned}
$$

In the above equations, $\omega_{r}$ is the rotor electrical speed where $\omega_{m}$ is the rotor mechanical speed. Figure 2 presents the overall simulation block diagram of Sensorless PMSM Drive Using EKF.

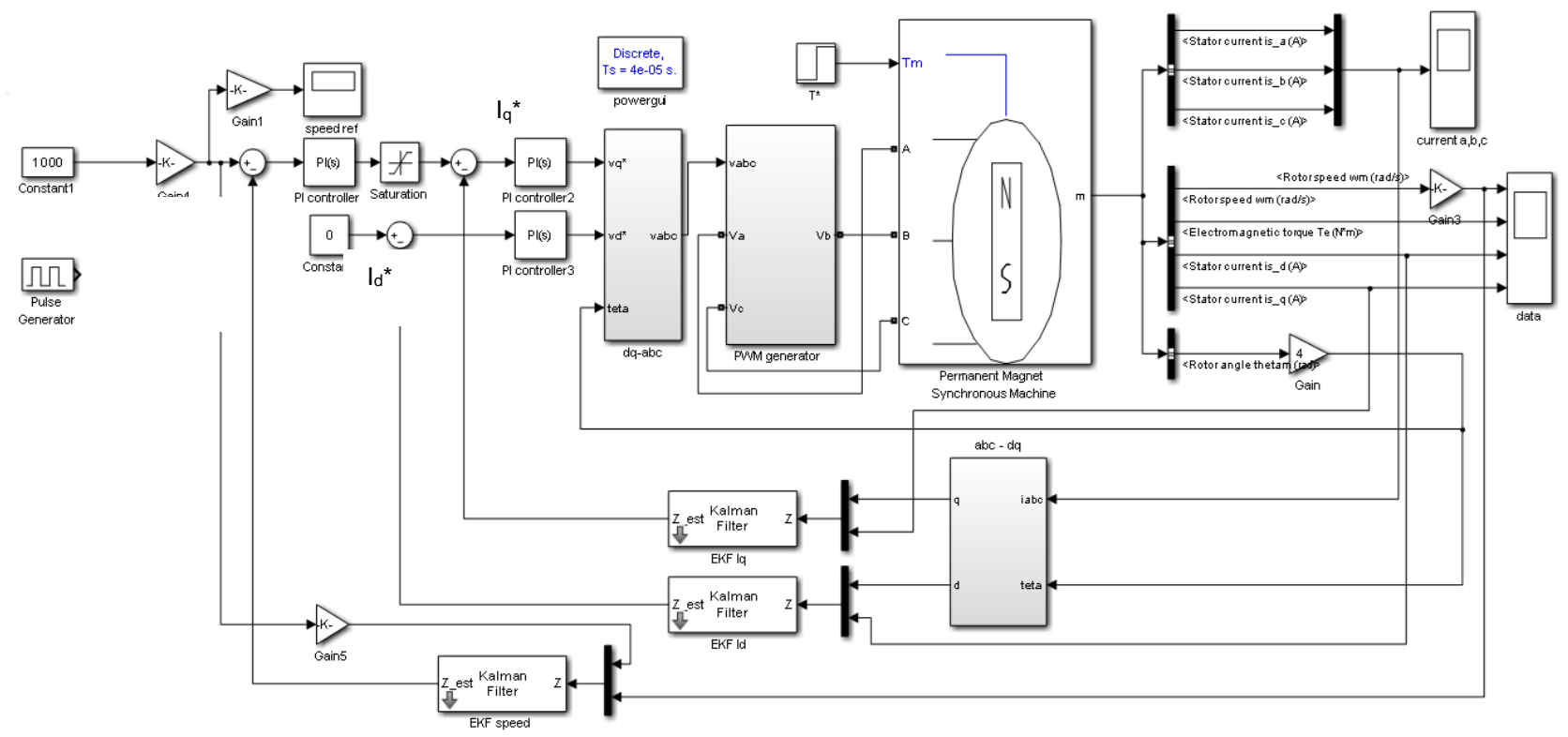

Figure 2 Overall Simulation Block Diagram for Sensorless PMSM Drive Using EKF

The drives system in Figure 2 starts with the reference torque current (ld*) which is equal to zero. This reference torque for current and speed is fed into the summation block to compare with the actual torque producing current and actual speed gain by PMSM. The comparison in the summation block producing error. The error from torque current will be moved into the current controller while an error from speed will move into the speed regulator block producing reference current of flux $\left(\mathrm{la}^{*}\right)$ and into the current controller block. Both current controllers producing torque voltage and flux voltage. Then it will be compared with coupling voltage in the summation block to produce the reference voltage. Both reference voltages $\left(V_{d^{*}}, V_{q}{ }^{*}\right)$ then fed into the converter which is converted from the $\mathrm{d}$-q component into 3-phase voltages, $V_{a}, V_{b}$ and $V_{c}$. The voltages now entering PWM generator block then into inverter block before supplying the PMSM. The currents and voltages from the motor are then converted into alpha and beta components. Both components entering the EKF algorithm block to calculate producing $I_{a}, I_{\beta}$, rotor angle $(\theta)$ and speed reference $(\omega)$. The reference currents now are converted into actual torque and flux currents including the speed, then are compared in the summation block earlier. The actual rotor angle is fed into park converter. So that is the overall scheme of sensorless vector control for PMSM using EKF.

\section{B. Extended Kalman Filter Algorithm}

In actual applications, the processes to be estimated are usually non-linear. Now the extended Kalman filter observer is applied to estimate the rotor speed that is feedback controlled by the PI regulator. By referring to Figure 2, the EKF observer is predicated on the error of the stator currents generated from their measured and estimated values that should be converged toward zero via defined style. Figure 3 shows the complete picture of the Kalman filter operation. 


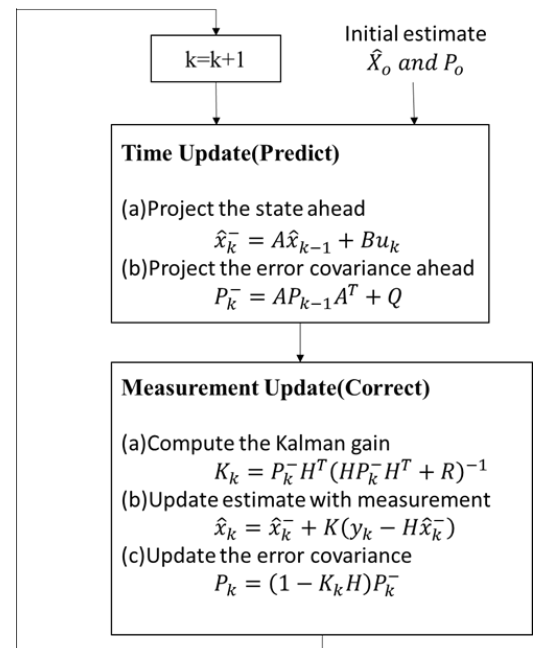

Figure 3 Kalman Filter Operation

The general problem of estimating the state $x \in \Re^{\Re}$ of a discrete-time process that is expressed by a linear stochastic difference equation. However, in actual applications, the processes to be estimated are usually non-linear. An extended Kalman filter (EKF) therefore is derived from the Kalman filter to solve this problem.

The non-linear relationships around the current time step can be linearized by using the partial derivatives of the process and measurement functions. To realize the linearization of a non-linear process, some parts in solution equations of the Kalman filter must be modified. Assuming $x \in R^{n}$ to be a state vector of a process, it can then be governed by the non-linear stochastic difference equation;

$X_{k}=f\left(x_{k-1}, u_{k}, \sigma_{k-1}\right)$

With measurement $y \in R^{n}$,

$y_{k}=h\left(x_{k}, \rho_{k}\right)$

Where the random variable $\sigma_{k-1}$ and $\rho_{k}$ represent the process and measurement noise. From Equation (12), the non-linear function $f$ relates the state at the previous time step $k-1$ to the state at the current time step $k$, and includes driving function $U_{k}$ and the zeromean process noise $\sigma_{k-1}$. In the measurement Equation (13), the non-linear function $h$ shows the relationship between the state vector $x_{k}$ and the measurement vector $y_{k}$.

The individual values of the noise $\sigma_{k}$ and $\rho_{k}$ at each time step are not known in actuality. However, the state and measurement vectors without noise could be approximated as:

$\widetilde{x}_{k}=f\left(\hat{x}_{k-1}, u_{k}, 0\right)$

$\tilde{y}_{k}=h\left(\tilde{x}_{k}, 0\right)$ where $\hat{x}_{k-1}$ is the posterior state estimation at the previous time step $k-1$. Thus a non-linear process can be approximately linearized as:

$x_{k}=\tilde{x}_{k}+A_{k}\left(x_{k-1}-\hat{x}_{k-1}\right)+W_{k} \sigma_{k-1}$

$y_{k} \approx \tilde{y}_{k}+H_{k}\left(x_{k}-\tilde{x}_{k}\right)+V_{k} \rho_{k}$

The prediction error and the measurement residual are define as:

$\tilde{e}_{x_{k}} \approx x_{k-} \tilde{x}_{k}$

$\tilde{e}_{y_{k}} \approx y_{k-} \tilde{y}_{k}$

EKF equations can be split into two groups:

1) Time update equations

$$
\begin{aligned}
& \hat{x}_{k}^{-}=f\left(\hat{x}_{k-1}, u_{k}, 0\right) \\
& P_{k}^{-}=A_{k} P_{k-1} A_{k}^{T}+W_{k} Q_{k-1} W_{k}^{T}
\end{aligned}
$$

2) Measurement update equations

$$
\begin{aligned}
& K_{k}=P_{k}^{-} H_{k}^{T}\left(H_{k} P_{k}^{-} H_{k}^{T}+V_{k} R V_{k}^{T}\right)^{-1} \\
& \widehat{x}_{k}=\widehat{x}_{k}^{-}+K_{k}\left(y_{k}-h\left(\widehat{x}_{k}^{-}, 0\right)\right) \\
& P_{k}=\left(1-K_{k} H_{k}\right) P_{k}^{-}
\end{aligned}
$$

The basic computing cycle of the discrete EKF is the same as that of the linear discrete Kalman filter shown in Figure 3.

\subsection{RESULTS AND DISCUSSION}

The simulation was performed based on three different tests which are, the speed-accuracy test, noise reduction test and the load torque test. The results are presented in Figures 4-6 below.

\section{A. Speed Accuracy Test}

In this simulation, the speed-accuracy for the proposed PMSM algorithm is tested for different speeds and depicted in Figure 4. This simulation test is divided by three conditions, $100 \%, 50 \%$ and $75 \%$ of rated speed which is $1000 \mathrm{rpm}$.

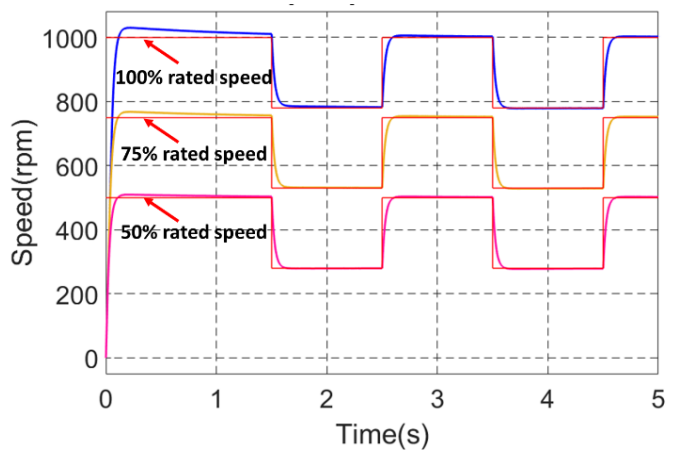

Figure 4 Speed behavior with EKF estimator 
The average steady-state speed error is $0.0004 \%$ at $1000 \mathrm{rpm}, 0.00021 \%$ at $500 \mathrm{pm}$ and $0.0092 \%$ at 250 rpm. The absolute value of the average steady-state speed error increase as the speed decreases because of the chopping noise factor and the dead time of PWM drive. The above result is listed in Table I. From the results of the simulation, it can be concluded that the proposed sensorless PMSM drive using EKF has good speed control accuracy, except at low speeds.

Table 1 Speed error of the simulation for speed accuracy test

\begin{tabular}{llll}
\hline $\begin{array}{l}\text { Reference speed } \\
\omega_{\text {ref }}\end{array}$ & $1000 \mathrm{rpm}$ & $\begin{array}{l}\text { Speed } \\
500 \mathrm{rpm}\end{array}$ & $250 \mathrm{rpm}$ \\
\hline $\begin{array}{l}\text { Steady-state error } \\
\omega_{\text {act }}-\omega_{\text {filter }}\end{array}$ & $-0.004 \mathrm{rpm}$ & $-0.006 \mathrm{rpm}$ & $-0.023 \mathrm{rpm}$ \\
$\begin{array}{l}\text { Steady-state } \\
\text { speed error ratio }\end{array}$ & $-0.0004 \%$ & $-0.0012 \%$ & $-0.0092 \%$ \\
$\frac{\omega_{\text {act }} \omega_{\text {filter }}}{\omega_{\text {ref }}} \times 100$ & & & \\
\hline
\end{tabular}

\section{B. Noise Reduction Test}

The simulation for the noise reduction test of the proposed sensorless PMSM drive using EKF is based on the results shown in Figure 5 and Table 2.

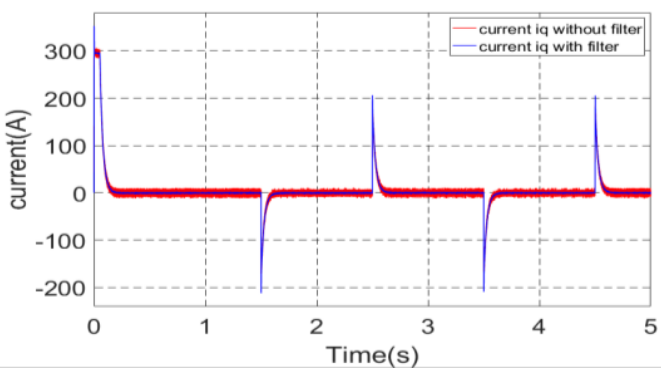

(a)

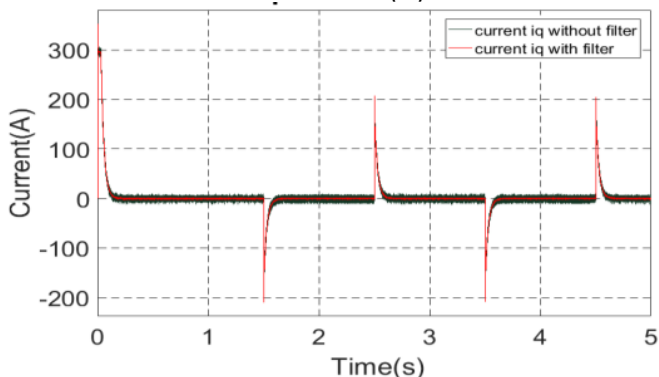

(b)

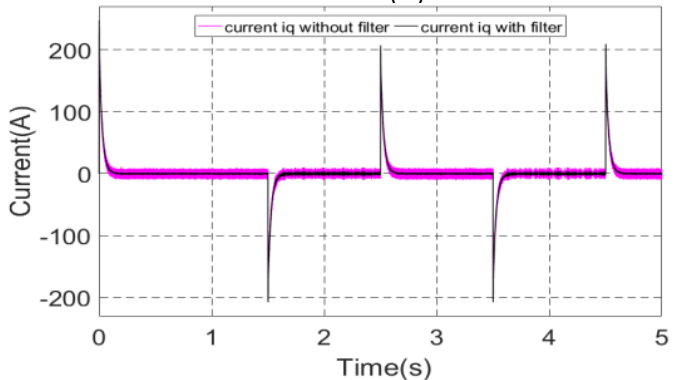

(c)

Figure 5 Simulation result of (a)current la at 1000 rpm, (b)current lq at $500 \mathrm{rpm}$, (c)current lq at $250 \mathrm{rpm}$
Figure 5(a), Figure 5(b) and Figure 5(c) show the wave-forms of the current $l_{a}$ with and without a filter at $1000 \mathrm{rpm}, 500 \mathrm{rpm}$ and $250 \mathrm{rpm}$. From the results of the simulation, it can be concluded that the proposed sensorless PMSM drive using EKF has good noise reduction, except at low speeds.

\section{Load Torque Test}

This simulation test is divided into two tests which are rotor speed at $100 \%$ and $50 \%$ rated speed. At each rotor, speed stages are applied with 100\%, 120\% and $50 \%$ of rated load torque which are $100 \mathrm{Nm}, 120 \mathrm{Nm}$ and $50 \mathrm{Nm}$. Figure 6 presents the rotor speed with load torque behaviour.

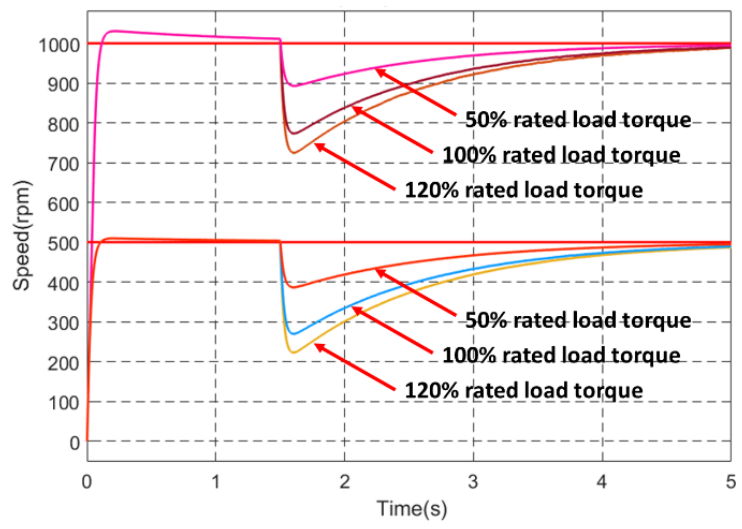

Figure 6 Speed with load torque behaviour

Figure 6 shows the waveform of the 2 different actual speeds which are $1000 \mathrm{rpm}$ and $500 \mathrm{rpm}$, with Torque Load TL applied at $t=1.5 \mathrm{~s}$. Figure 6 also shown three different TL which are $120 \mathrm{Nm}, 100 \mathrm{Nm}$ and 50 $\mathrm{Nm}$.

The overshoot and rise time for responses are represented in Table 2. And the overshoot during load applied is tabulated in Table 3.

Table 2 Overshoot and rise time of the speed response

\begin{tabular}{ccc}
\hline Ref. speed $\omega_{\text {ref }}$ & Overshoot (rpm) & Rise Time (s) \\
\hline $1000 \mathrm{rpm}$ & 30 & 0.2 \\
$500 \mathrm{rpm}$ & 9 & 0.2 \\
\hline
\end{tabular}

Table 3 undershoot and settling time during the loaded condition

\begin{tabular}{ccccc}
\hline $\begin{array}{c}\text { Load, TL } \\
\text { (NM) }\end{array}$ & $\begin{array}{c}\text { Speed 1000rpm } \\
\text { Undershoot } \\
\text { (rpm) }\end{array}$ & $\begin{array}{c}\text { Settling } \\
\text { Time (s) }\end{array}$ & $\begin{array}{c}\text { Speed 500rpm } \\
\text { Undershoot } \\
\text { (rpm) }\end{array}$ & $\begin{array}{c}\text { Settling } \\
\text { Time } \\
\text { (s) }\end{array}$ \\
\hline 120 & 247.8 & 3.4 & 277.9 & 3.4 \\
100 & 226.8 & 3.1 & 230.3 & 3.2 \\
50 & 107.1 & 2.9 & 113.4 & 3.0 \\
\hline
\end{tabular}

From the result, it can be summarized that overshoot will increase as speed reference increase. 
Next, undershoot and recovery time will increase as load torque is increase. From the result of simulation, it can be concluded that the proposed sensorless PMSM drive using EKF has good robustness for variation of load.

\subsection{CONCLUSION}

In this paper, the modelling, analysis and design validation of a robust and noise reduction sensorless control method for permanent magnet synchronous motor (PMSM) using Extended Kalman Filter (EKF) to accurately estimate rotor speed and current has been presented. A Matlab/Simulink based dynamic model and modulation technique for the PMSM has been developed and implemented. Detailed simulations and analysis of the proposed sensorless PMSM drive using EKF have been presented which validate the robustness, noise reduction and accuracy of the proposed sensorless method. The specifications of the PMSM are listed in Table 4.

Table 4 Specifications of the PMSM

\begin{tabular}{lcc}
\hline No. & Parameter & Specification \\
\hline 1 & Motor Power & $20 \mathrm{KW} / 14.92 \mathrm{HP}$ \\
2 & Rated Speed & $1000 \mathrm{RPM}$ \\
3 & Rated torque & $100 \mathrm{Nm}$ \\
4 & Rated current & $296 \mathrm{~A}$ \\
5 & Rated voltage & $176 \mathrm{~V}$ \\
6 & Number of poles & 4 \\
7 & $\mathrm{~L}_{d}$ & $0.3595 \mathrm{mH}$ \\
8 & $\mathrm{~L}_{\mathrm{a}}$ & $0.695 \mathrm{mh}$ \\
9 & $\mathrm{R}_{\mathrm{s}}$ & $6.5 \mathrm{~m} \Omega$ \\
10 & Flux $\left(\varphi_{\mathrm{m}}\right)$ & $0.080 \mathrm{~Wb}$ \\
11 & Inertia $(\mathrm{J})$ & $0.1 \mathrm{kgm}{ }^{2}$ \\
12 & Damping Coefficient(B) & 0 \\
\hline
\end{tabular}

\section{Acknowledgement}

The author would like to acknowledge "Centre of Robotic \& Industrial Automation" (CERIA), "Centre of Research and Innovation Management" (CRIM), Universiti Teknikal Malaysia Melaka (UTeM) and Ministry of Higher Education Malaysia (MOHE) for supporting this project.

\section{References}

[1] B. W. Harini, F. Husnayain, A. Subiantoro, F. Yusivar. 2020. Asynchronizational Loss Detection Method for PMSM Speed Sensorless Control. Jurnal Teknologi (Sciences \& Engineering). 82(4): 47-54.

[2] M. Dubey, S. Sharma and R. Saxena. 2016. Single Stage PV System based Direct Torque Controlled PMSM Drive for Pump Load Application. 2016 IEEE International Conference on Power Electronics, Drives and Energy Systems (PEDES). 1-5.
[3] Wang, Q., Wang, S. and Chen, C. 2019. Review of Sensorless Control Techniques for PMSM Drives. IEEJ Trans Elec Electron. Eng. 14(10): 1543-1552.

[4] S. Sakunthala, R. Kiranmayi and P. N. Mandadi. 2017. A Study on Industrial Motor Drives: Comparison and Applications of PMSM and BLDC Motor Drives. 2017 International Conference on Energy, Communication, Data Analytics and Soft Computing (ICECDS). 537-54.

[5] Bose, B. K., Godoy Simoes, M., Crecelius, D. R., Rajashekara, K. and Martin, R. 1995. Speed Sensorless Hybrid Vector Controlled Induction Motor Drive. Industry Applications Conference. Thirtieth IAS Annual Meeting, IAS '95, Conference Record of the 1995 IEEE, 8-12 Oct. 1: 137143.

[6] O. Benjak and D. Gerling. 2010. Review of Position Estimation Methods for PMSM Drives without a Position Sensor, Part III: Methods based on Saliency and Signal Injection. 2010 International Conference on Electrical Machines and Systems. 873-878.

[7] D. Yousfi, A. Halelfadl and M. El Kard. 2009. Review and Evaluation of Some Position and Speed Estimation Methods for PMSM Sensorless Drives. 2009 International Conference on Multimedia Computing and Systems. 409414.

[8] J. Holtz. 1993. Speed Estimation and Sensorless Control of AC Drives. Industrial Electronics, Control, and Instramentation. Proceedings of the IECON '93, International Conference on, 15-19 Nov. 2649-654.

[9] Ogasawara, S. and Akagi, H. 1991. An Approach to Position Sensorless Drive for Brushless DC Motors. Industry Applications, IEEE Transactions on, Sept.-Oct. 27(5): 928933.

[10] Lazi, J. M., Ibrahim, Z., Talib, M. H. N., Alias, A., Nur, A., Azri, M. 2019. Speed and Position Estimator of for Sensorless PMSM Drives using Adaptive Controller. International Journal of Power Electronics and Drive Systems, (IJPEDS). 10(1): 128-36.

[11] E. S. Park, K. J. Joo, I. G. Kim, H. W. Lee, and J. Lee. 2016. Speed-sensorless Control for Permanent Magnet Synchronous Motor using MRAS Method with Reduced Order Observer. 18th Int. Conf. Electr. Mach. Syst. ICEMS 2015. 814-817.

[12] P. Karlovský and J. Lettl. 2017. Improvement of DTC Performance using Luenberger Observer for Flux Estimation. 18th International Scientific Conference on Electric Power Engineering (EPE). 1-5.

[13] Karlovsky, Pavel \& Lettl, Jiri. 2017. Improvement of DTC Performance using Luenberger Observer for Flux Estimation. 18th International Scientific Conference on Electric Power Engineering (EPE). 1-5.

[14] M. Comanescu and T. D. Batzel. 2009. Reduced Order Observers for Rotor Position Estimation of Nonsalient PMSM. 2009 IEEE Int. Electr. Mach. Drives Conf. IEMDC '09. 1346-1351.

[15] M. Comanescu and T. D. Batzel. 2009. Reduced Order Observers for Rotor Position Estimation of Nonsalien PMSM. IEEE Int. Electr. Mach. Drives Conf. IEMDC '09. 13461351.

[16] E. S. Park, K. J. Joo, I. G. Kim, H. W. Lee, and J. Lee. 2015. Speed-sensorless Control for Permanent Magnet Synchronous Motor using MRAS Method with Reduced Order Observer. 18th Int. Conf. Electr. Mach. Syst. ICEMS 2015. 814-817.

[17] Z. Liu and Y. Huang. 2016. Complementary Sliding Mode Control for PMSM Speed Regulations with Adaptive Switching Gain. Chinese Control Conf. CCC, 2016-August. 4499-4503.

[18] Chi-Ying Liang, Juhng-Perng Su. 2003. A New Approach to the Design of a Fuzzy Sliding Mode Controller. Fuzzy Sets and Systems. 139(1): 111-124.

[19] Y. Wang, K. Li and X. Liu. 2019. Improved Deadbeat Control for PMSM with Terminal Sliding Mode Observer. 22nd International Conference on Electrical Machines and Systems (ICEMS). 1-5. 
[20] Termizi, M. S., Lazi, J. M., Ibrahim, Z., Talib, M. H. N., Aziz, M. J. A., Ayob, S. M. 2017. Sensorless PMSM Drives using Extended Kalman Filter (EKF). 2017 IEEE Conference on Energy Conversion, CENCON 2017. 2018(January): 145150.

[21] W. H. Ali, M. Gowda, P. Cofie and J. Fuller. 2014. Design of a Speed Controller using Extended Kalman Filter for PMSM. 2014 IEEE 57th International Midwest Symposium on Circuits and Systems (MWSCAS). 1101-1104.
[22] O. Asseu, P. Yobove, A. Konate and M. Diaby. 2017. An Extended Kalman Filter Algorithm for a PMSM: Experimental Results. Asian Journal of Applied Sciences. 10(1): 32-38.

[23] K. Kendouci, B. Mazari, M. R. Benhadria and R. Dadi. 2015. Speed-sensorless Direct Torque and Flux Control of PMSM based on Extended Kalman Filter using Space Vector Modulation. 3rd International Conference on Control Engineering \& Information Technology (CEIT). 1-5. 